International Journal of Inclusive Education

\title{
Title
}

\section{Illuminating young children's perceived notions of inclusion in pedagogical} activities.

\section{Authors}

Patricia A. Shaw, School of Education and Social Sciences, Faculty of Arts, Culture and Education, University of Hull, Hull, HU6 7RX, UK. Tel: +44 (0)1482 462084. Email: Patricia.shaw@hull.ac.uk [corresponding author].

Kyriaki Messiou, Southampton Education School, Building 32, Room 1021, University of Southampton, SO17 1BJ. Tel: +44 (0)2380 59 2642. Email: K.Messiou@ soton.ac.uk

Chronoula Voutsina, Southampton Education School, University of Southampton, SO17 1BJ, UK. Tel.: +44 (0)2380 59 2756. Email: $\underline{\text { cv@soton.ac.uk }}$

\section{Date submitted}

$13^{\text {th }}$ December 2018 


\title{
Illuminating young children's perceived notions of inclusion in pedagogical activities.
}

\begin{abstract}
This paper presents findings from a research study, which sought to illuminate the perceived notions of inclusion of four to five year old children in pedagogical activities, in the early years classes of two schools in the North of England. It employed a qualitative methodology to gather extensive data with forty children over a six-week period in each school. This included collecting fieldnotes; undertaking observations of children in pedagogical activities; and conducting group and individual interviews. Central to the research aim was the use of participative tools to engage with children's voices; these included photographs and drawings. Children's perceived notions of inclusion resonated with two dimensions: belonging and relationships (with practitioner and/or child) and democratic pedagogies. The findings advance the conceptualisation of the notion of inclusion and bring to the fore the voices of a young group of children that has not been studied before. Engaging with children in meaningful ways can enable practitioners to better understand young children's perceived, multi-faceted notions of inclusion as they experience it within pedagogical activities.
\end{abstract}

Key words: engaging with voices; early years; inclusion; belonging and relationships; democratic pedagogies

\section{Introduction}

Article 12 of the United Nations Convention on the Rights of the Child (UNCRC 1989) conveys the notion of engaging with children's voices and espouses the ethos of listening. It states that all children have the right to express their views and that they will be heeded, and moves towards engaging with children's views as 'a moral perspective on the role and status of children which respects and promotes their entitlement to being considered as persons of value and persons with rights' (Greene and Hill 2005, 3). However, MacNaughton, Hughes and Smith $(2007,458)$ connote that there is 'little empirical evidence to support the contention that consulting young children is valuable' - a view that reflects the scarcity of research with young children. Possible reasons for this lack of engagement with young children are that ' $[\mathrm{T}]$ they have been regarded as undeveloped, lacking even basic capacities 
for understanding, communicating and making choices' (Office of the High Commissioner for Human Rights 2005, 7).

This research contests the perspective that young children lack the capacity to express opinions about their inclusion in educational experiences, and it reflects Allan's (2007) premise that the voices of those who have the most direct experience of inclusion must be present. It responds to, and challenges, the constant theme of powerlessness and exclusion felt by children, and reflects Messiou's $(2006,40)$ view that children are 'considered as one of the marginalized groups whose voices have been neglected within inclusive education.' Since the majority of children consulted in research, have been in their formal years of schooling or older (Children and Young People's Unit, 2004), it emphasises the importance of affording the voices of younger children the same prominence as older children.

\section{Research aim}

The research aim for this study was to illuminate children's perceived notions of inclusion in pedagogical activities in the Reception class (children aged four to five years in their first year of formal schooling). This was explored through the research question: In what ways do children perceive pedagogical activities as promoting or hindering inclusion in the Reception class? It was conducted in the Reception classes of an infant and a primary school in the North of England. Pedagogical activities are defined as the instructional techniques and strategies that enable learning to take place, and which provide opportunities for the acquisition of knowledge, skills and attitudes within a particular social context (SirajBlatchford et al. 2002).

Regarding pedagogy, different theories underpin or contribute to a country's pedagogical principles. Within the practice and observable pedagogy in England's early years education, Stephen $(2010,18)$ refers to two 'big ideas'. The first is concerned with provision that is child-centred and offers children opportunities to choose how to spend their time; the 
second emphasises play as the medium through which children learn. However, an exploration of the literature surrounding the quality of early years education in England (Siraj-Blatchford et al. 2002), reveals that these 'big ideas' are not sufficiently emphasised in curriculum documents such as the Early Years Foundation Stage (EYFS) (DfE 2014). Indeed, the EYFS refers to the need to move towards more adult-led activities, so that children can be 'prepare(d) for the more formal learning of Year 1' (DfE 2014, 9).

In seeking children's perceptions of inclusion, the study was designed to reflect the shift in acknowledging the importance of children's voices within English legislation (Educational Needs and Disability (SEND) Code of Practice: 0 to 25 years, DfE 2015) and to evaluate its findings in relation to international policies and legislation. It advances the conceptualisation of the notion of inclusion and brings to the fore the voices of a young group of children that has not been studied before.

\section{Principles of inclusion}

Contested and complex issues exist within the discourse concerning inclusion (Florian 2008). Campbell (2002) describes the key aspects of the inclusion debate as being a balance between individual needs and those of the majority; the active participation of pupils; an ongoing process; and its relation to exclusion. Some, even suggest that inclusion has become something of a cliché (Thomas and Loxley 2007), 'an international buzzword'(Benjamin 2002, viii) devoid of meaning. Slee (1998) argues that inclusion can often connote a linguistic adjustment that provides a politically correct response to a changing world. Hence, inclusion has come to mean different things to different people, different things at different points in time, and different things in different locations (Ainscow, Booth and Dyson 2006), or a 'semantic chameleon' (Liasidou 2012, 5). This creates possibilities for inclusion to become a unique picture across different settings, a rather 'elusive' idea (Ainscow 1999) situated in a weakened position without clarity and transparency. Slee (2001), in concurrence with 
Dyson's (1999) reference to 'inclusions', suggests that people place their own lens on their justification of inclusion.

This paper locates inclusion within the following principles: responding to the diverse needs of all children through increased participation (Booth and Ainscow 2004); sharing power more equally between adult and child (Blenkinsop 2005); and belonging and relationships (O’Brien and Forest 1989). The first two principles were intrinsic to the design of the study by including all the children in the data collection. Messiou (2016), in her analysis of published articles in the International Journal of Inclusive Education between 2005 and 2015, highlights that most studies in the field of inclusive education are only concerned with certain groups of learners. She argues that concentrating on specific groups of children, rather than on all, is at odds with the ideologies of inclusion.

By acknowledging the importance of participation in empowering children as learners, the study enabled children to express their ideas and opinions and develop a positive sense of self (Bruce 2005). Consequently, the final principle became noteworthy since within an early years context, there is an association between children's developing sense of self and identity, and belonging. This acknowledges children's interdependence with others and forms the basis of relationships in defining identities (Department of Education Employment and Workforce Relations 2009).

\section{Belonging and relationships}

The prominence of belonging for young children has been formalised in curriculum documents such as New Zealand's Te Wha ${ }^{-}$riki (Ministry of Education 1996) and Australia's Belonging, Being and Becoming: The Early Years Learning Framework (Department of Education Employment and Workforce Relations 2009). Yet, within the English curricula (DfE 2014), there is no specific mention of belonging. 
Baumeister and Leary's (1995) belongingness hypothesis defines belonging as the extent to which individuals feel personally accepted, respected, included, and supported by others in their social environment. Connections between belonging and inclusion are emphasised by the subjectivity of experiences and central to their understanding are the thoughts, feelings and experiences of children (Schwandt 1997). Belonging can therefore be experienced in diverse and multiple ways that vary from person to person (Yuval-Davis 2006), and thus, it may be represented as multidimensional and complex - belongings rather than belonging. Just as inclusion is not a fixed state (Booth and Ainscow 2004), neither is belonging; rather it is a dynamic process (Sumsion and Wong 2011).

\section{Democratic pedagogies}

Moss (2007) attests that inclusion can also be viewed through the lens of democracy, since its presence in early education and care provides possibilities for diversity to flourish. However, just as there is no reference to belonging in the English early years curricula (DfE 2014), he concedes that there is also no mention of democracy, despite it being explicitly recognised as a value in other early years curricula (e.g. Nordic countries). The implication is that democracy is not foregrounded in English governmental policy, despite it being identified as important for ensuring that values are shared by all and that everyone is able to voice their views on issues that matter to them (Cagliari, Barozzi and Giudici 2004).

By acknowledging a child's agency in their learning, children should be afforded autonomy since they are the one who cause things to happen (Rathbone 1971). Candy (1991) refers to learner autonomy as a perennial dynamic process amenable to educational interventions rather than a static product, which is strongly aligned with Ainscow's (2005) principle of inclusion as an on-going process. Rathbone's view of the learner as an active agent, however, appears to underestimate the influence of power within the learning process. Blaise and Ryan (2012) examine whose agency, power and interests are exercised or 
marginalised in these instances. Although the communication of agency may occur in multiple ways through children's engagement in a range of activities, it may also be articulated as the freedom to make choices. However, freedom does not always place children in control, nor are they always empowered (Wood 2014). Thus, it becomes important to consider how children can be incorporated within dialogue about the development of more inclusive environments.

\section{Engaging with children's voices}

In recent years, perspectives of childhood have challenged the assumptions about children's inability to make decisions in their own best interests (Turnbull, Fattore and Calder 2008). James and James (2008) recognise children's agency as that which affords them opportunity to shape and negotiate aspects of their childhood. However, the basis for reference to children having authority over their voice is an assumption that they possess one homogenous voice or culture (Woodhead 2009). Some researchers (Levin 1994; Ritala-Koskinen 1994) argue that children do not live as one cultural grouping and that there is no single concept of childhood. This suggests that different children may have contradictory wishes and expectations, all of which are equally valid and to which one should listen accordingly. Nutbrown and Clough (2009) acknowledge that whilst it may be difficult to respond to these diverse voices, changes in practices and settings can make the place more inclusive and enabling for all who attend.

The importance of engaging in dialogue with children themselves is emphasised here, which can be helpful in revealing issues surrounding perceptions of inclusion. However, the term voice is itself problematic since it does not always retain the same meaning. Hadfield and Haw (2001) purport that voice has become such a broadly used term that it is in danger of losing much of its specific meaning as it becomes disconnected from the different theoretical sources and critical praxis from which it originated. Komulainen (2007) concurs, emphasising that voice can become sensationalised, whilst assuming that adults can exchange 
and match children's thoughts to different situations. Therefore, the concept 'engaging with voices' (Cruddas 2006) is adopted, which operates within a socially constructed space, promoting the analysis of both child and adult voices and avoiding an over reliance on adult ways of listening to children.

Concerns about engaging with children's voices are particularly evident within the early years. Article 12 of the UNCRC (1989) refers to giving due weight to children's voices, however, it is couched in the ambiguous language of being in accordance with the age and maturity of a child who is capable of forming his or her own views. This exemplifies the lack of understanding of how young children can express their views. Malaguzzi (1993) informs that children have a hundred languages such as playing, thinking or speaking, all of which enable the understanding of the endless number of children's potentials. Therefore, the affordance of opportunities that are genuine and meaningful in engaging with children's voices need to be developed, to provide a multitude of means by which they might communicate (Clark, McQuail and Moss 2003). The inclusion of young children's voices in research necessitates the utilisation of suitable methods and methodologies that are capable of empowering children to share their lived experiences and perspectives.

\section{Children's understanding of inclusion}

Since abstract concepts such as inclusion are inherently difficult to discuss with young children, the children were informed of the study's research aims using pictures of different pedagogical activities. These images depicted children learning in different environments, with their peers and/or with a teacher, and in differing pedagogical activities. During discussions it emerged that the children connected inclusion with notions of knowing what to do (Hedges and Cullen 2011), being able to play with their friends (Booth and Ainscow 2004), and with the teacher helping the children to learn (Jordan 2004). 


\section{Methodology and research design}

A qualitative methodological approach to data collection was adopted that operates within a constructivist and interpretivist paradigm, where categories and meaning are socially constructed (Bryman 2012). Consideration was given to issues of consent, assent and dissent (Dockett, Perry and Kearney 2012).

All children in the Reception classes were invited to participate in the research. On receipt of parental consent, 21 children at Riverside Infants (RI) and 19 children at Oak Ridge Primary (ORP) partook in the study. The use of pseudonyms for the children and schools ensures anonymity. The collection of data during a three-month period facilitated the researcher's relationships with the children and enabled them to feel more at ease when engaging in conversations about the research. Additionally, discussions around assent and dissent were conducted with the children to ensure that ethical principles were maintained throughout. The presentation of data from 14 children across both schools, and which are representative of a wider range of children's perceptions of inclusion, illustrate the key themes.

\section{Research tools}

To explore notions of inclusion in greater depth, a range of methods were employed, all of which are included within this paper. These were unstructured (UO) and structured observations of pedagogical activities using the Leuven Involvement Scale (LIS) (Laevers 1994); semi-structured group interviews using diamond ranking (DR); and drawing activities with individual children (I).

\section{Observations}

Participant unstructured and structured observations using the LIS (focusing on central indicators of quality in early years' provision - children's well-being and involvement), were adopted as suitable data collection instruments for research with young children (Rolfe, 
Freshwater and Jasper 2001). The LIS was utilised since Laevers asserts that if interactions are secure, children's well-being will enable them to become stronger and inform adults about their feelings and emotions; this could ultimately affect their perceptions of inclusion. Both forms of observations facilitated the collection of detailed and extended contextual information that offered rich data about children's engagement with both their learning environment and their peers.

\section{Group interviews}

Following four weeks of observations, group interviews were undertaken during which discussions about the inclusion of children in pictures comprising different pedagogical activities ensued. Children were asked to order photographs of different pedagogical activities occurring in each school in a diamond ranking activity, according to which ones they felt most included. Diamond ranking is a thinking skills tool (Rockett and Percival 2002) where items representing a spread of perspectives are sorted and ranked in a diamond fashion, with the most important at the top and the most unimportant at the bottom. Its strength lies in the premise that when people rank items, they are required to make explicit, the rationale for how they are organised through the process of discussion, reflection and negotiation with other group members (Clark 2012).

Interviews were documented on a digital recorder, and were employed as 'a flexible tool for data collection, enabling multi-sensory channels to be used: verbal, non-verbal, spoken and heard' (Cohen, Manion and Morrison 2007, 349). Photographs were selected as an instrument to evoke deeper responses, thoughts, feelings and memories from the children (Collier 1957), rather than tools which rely on more traditional modes of communication.

Creative visual methods can be helpful in addressing the underrepresentation of children in research (Boxall and Ralph 2009), challenging traditional adult-controlled power dynamics and equalising power relationship between researchers and children. 


\section{Children's drawings}

The final data collection tool involved the use of drawings during individual interviews. This enabled children to consider further, the questions asked in the group interviews, and assist them in reflecting and processing any emotions or thoughts that may have arisen (Picard, Brechet and Baldy 2007). Drawings can also assist adults in understanding children's perceptions, thoughts and experiences (Dockett and Perry 2005). Additionally, drawing is often very successful as it forms part of the fun and relaxing everyday experiences of children (Fargas-Malet, et al. 2010) and minimizes the power relationship between researcher and child (Smart 2009).

However, their interpretation can be problematic as there is a danger of projecting adults' perspectives onto children's drawings (Angelides and Michaelidou 2009). Responding to Jameson's (1968) suggestion that the description of a drawing after its completion can be misleading, the researcher sat near the children so that she could hear them talking, which offered the possibility of a different perspective.

\section{Data analysis}

On completion of the data collection, transcription occurred for all interviews and observational data and facial expressions and body language were noted. An inductive approach to coding was adopted, in which the researcher allows the theory to emerge from the data (Strauss and Corbin 1998), by considering the frequent, dominant, or significant themes inherent in raw data, without the restraints imposed by structured methodologies (Thomas 2006). The stages of coding were: preparation of raw data; close reading of data; creation of categories; overlapping, merging and deleting of codes; and creation of themes and dimensions. A thorough analysis of the data revealed that some codes were similar, such as 'being kind' and 'children are friendly'. In these cases, codes were merged into categories, so long as the codes were not distorted in the process. Additionally, close attention was paid 
to children's words and body language regarding their perception of the promotion or hindrance of inclusion. The final analysis stage revealed a connection between some of the categories (e.g. 'I can do the work' and 'cos I don't need any help'), which led to the creation of key themes (e.g. Independent achievement) and subsequent dimensions (table 1). 
Table 1. Emergent key themes and subsequent dimensions.

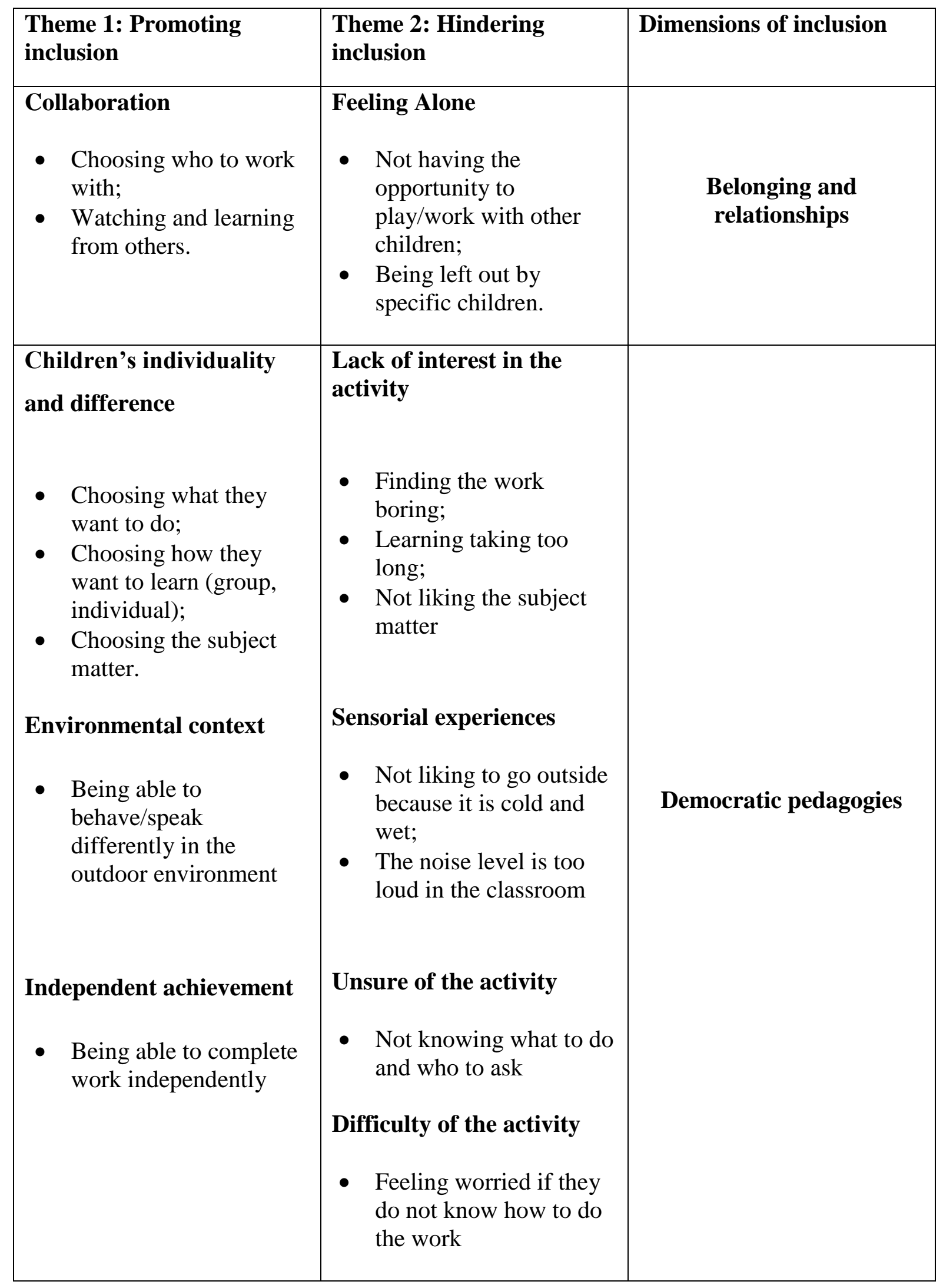




\section{Findings and discussion}

Inductive data analysis led to the identification of two dimensions: belonging and relationships; and democratic pedagogies.

\section{Belonging and relationships}

Two areas that children identified as important to their inclusion in pedagogical activities, and which relate to belonging and relationships, are Collaboration and Feeling Alone. Collaboration is significant, since children from both schools commented that they perceived themselves to be included when they were working with, or learning from, another. This indicates a connection with another person, or a sense of belonging. The relationship between inclusion and collaboration is emphasised by children's comments about how they perceived themselves to be included when they could work with another child or practitioner ' $C o s$ I like playing football with George’ (ORP I Jacob); 'Working with other people’ (RI I Olivia).

Furthermore, some commented that they perceived themselves as less included when they had to work on their own, 'Because no-one's with me' (ORP I Evelyn), which resonates with the notion of feeling alone.

A remark made by Scarlet (RI I) provides a thought-provoking comment on which to reflect. She mentioned that she "feeled alone" when she was unable to play with other children. Observations of other children, such as Aiden (ORP), who displayed high levels of well-being and involvement whenever he was playing with other children (UO), reinforce the connection between inclusion and belonging. When using the construction equipment, Aiden (LIS) was observed being spontaneous and expressive; energetic; and persisting with the activity.

Some children extended their perception of inclusion beyond simply working with other children to working with specific children or friends. By selecting particular children 
with whom to work, children in the study demonstrated the importance they placed on the formation of relationships. James (RI I), for example, drew pictures that revealed he perceived himself to be included when he was with his friend (figure 1) and not included when he was on his own (figure 2).

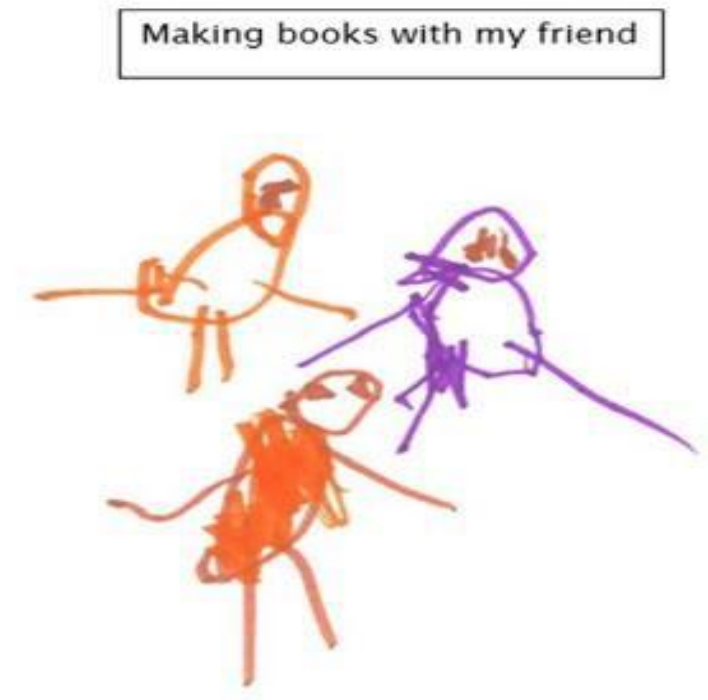

Figure 1. James's drawing of a pedagogical activity in which he perceives himself to be included.

When I'm on my own

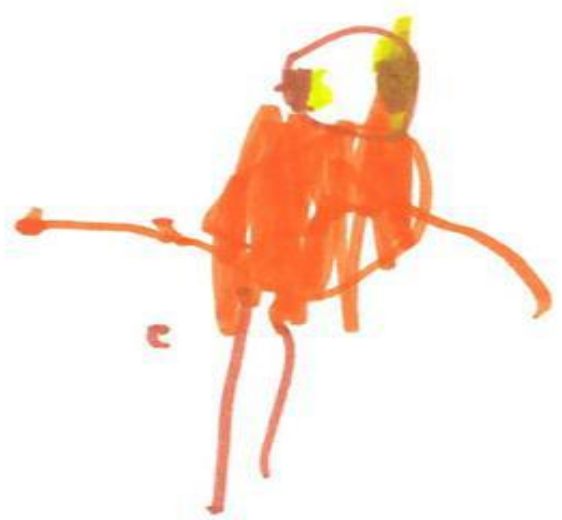

Figure 2. James's drawing of a pedagogical in which he does not perceive himself to be included. 
An interview with Scarlet (RI I) reaffirms the importance placed on relationships. She explained that she did not perceive herself to be included, 'But sometimes I really don ' $t$ ' because 'my friends were mean to me'. In her drawing (figure 3), Scarlet depicts her friends smiling, however, the picture of herself initially had a smiling mouth, but she later altered it to a sad one, explaining 'Cos I'm not happy'. Whilst happy does not necessarily equate with not being included, when coalesced with Scarlet's comments about feeling alone and being excluded from an activity by her friends, the argument is strengthened.

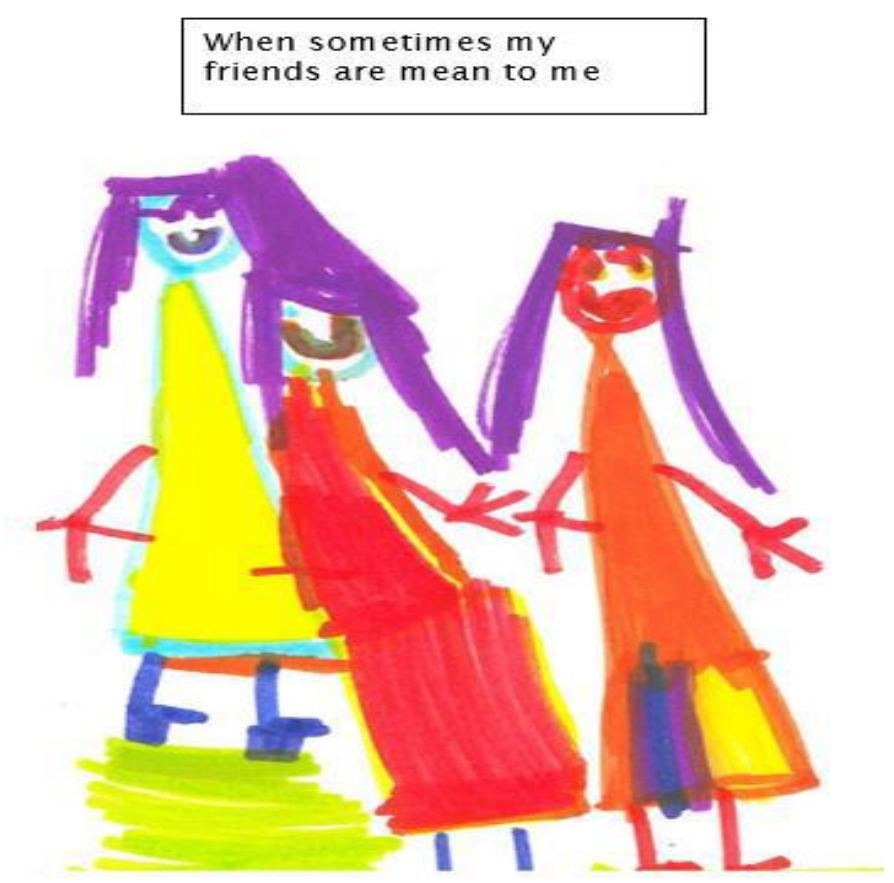

Figure 3. Scarlet's drawing of a pedagogical activity in which she does not perceive herself to be included.

Luke (ORP DR), who perceived himself to be included when he was working individually with a teacher, explicates the importance of the relationship between child and practitioner. 'Cos I like working with the teacher to do my handwriting, cos if the teacher shows.' An observation of Luke listening to the teacher during a large group activity in a similar area, strengthens this interpretation, since he displayed little emotion; was distracted; 
had limited energy; and made only slight progress (LIS). Whilst the observation and interview cannot emphatically conclude that Luke's relationship with the teacher influenced his perception of inclusion, it is important not to let the uncertainty detract from Luke's actual words and opinions.

Henry's (RI I) comment, “it's so long to choose me" reaffirms this interpretation, and extends it to consider the impact of the proximity to a practitioner and the lack of individual attention, to his perception of inclusion. An observation comes from Henry in a large group mathematics lesson. His facial expressions and actions indicated he was ill at ease; did not join in with the activity; showed no interest at all; and began to disrupt the lesson (LIS). However, when an adult closely supported Henry during a large group activity, at its inception, he displayed negative facial expressions and his arms were crossed, but later he talked to the adult next to him, raised his hand to ask and answer questions and was not distracted by the children around him (LIS). These external behaviours are interpreted as increased inclusion in the pedagogical activity, which indicates that the proximity, or ability to speak to a practitioner, is an important dimension in determining a child's perception of inclusion.

These examples personify the importance that children placed on working or playing in collaboration with others, which resonates strongly with the tenet of inclusion and participation (Booth and Ainscow 2004). They exemplify Baumeister and Leary's (1995) theory of a sense of belonging, described as the extent to which individuals feel personally accepted, respected, included and supported by others in their social environment. It is contended that this definition also reflects the principles of inclusion; if others accept a child within their pedagogical activities, it is conceivable that the child might perceive themselves as more included. 
The findings are similar to those of Allodi Westling (2002), Einarsdottir (2010), and Kragh-Müller and Isbell (2011), who report that children need to build friendships and to play with peers to be able to thrive. They resonate strongly with Malaguzzi’s (1993) description of an education based on relationships that emphasise socially embedded processes, and as the emotional connections occurring through both verbal and non-verbal social interactions among children, and between children and practitioners (Joerdens 2014). Similarly, Lundquist, Allodi Westling and Siljehag (2018) report that for children to maintain and develop positive experiences of early school years, they value and need to feel, a sense of belonging with their peers.

Bennett's (2011) research indicates the importance of relationships between and among children, which supports their sense of belonging, and in turn endorses the development of social identity - a sense of self in relation to others. The development of social identity, may account for why some children placed greater importance on working with others to perceive themselves as included. Children, who had not sufficiently developed their sense of self, may have sought the reassurance from others to support their feelings of belonging and therefore inclusion. Thus, belonging is considered a dimension of children's perceived notions of inclusion in pedagogical activities, which can manifest itself through the relationship with another child and/or practitioner.

\section{Democratic pedagogies}

Two notions that children identified as important to their inclusion, and which relate to democratic pedagogies are, Children's interests and Autonomy over the content, context or mode of delivery of the pedagogical activity. Regarding children's interests, Leo (RI) referred to being included when he was able to learn about matters that were of interest to him and did not perceive himself to be included when the content was boring. Observations also noted differing levels of well-being and involvement in a variety of large group 
activities. Freya's (RI) external behaviour in different group activities, seemed to imply that it was the content, rather than group activity per se, that influenced her perception of inclusion. She was observed displaying higher levels of well-being and involvement in a group phonics sessions than in group activities focusing on mathematics (LIS).

The connection between autonomy and children's perceived notions of inclusion comes from the expression of different interpretations of the same pedagogical activity. It is interesting to note that most of these comments came from children at Riverside Infants, where grouping occurred according to perceived ability. In contrast, children at Oak Ridge Primary were able to access pedagogical activities according to their own wishes. For example, when asked why she felt most included in large group activities, Hannah (ORP DR) replied 'Because I was listening to the teacher and what she says', whereas Daniel (RI I) explained that he did not feel included 'Cos it's too boring'.

Examples referring to the outdoor environment, portray Nathan (ORP DR) perceiving himself to be included because 'I can breathe the air out of my mouth'; and Jack (RI I) 'Because I can shout outside'; whereas Emma (RI I) did not perceive herself as included 'Cos I hate going outside, cos it's so .. I thought it was going to rain (whispers). And it's freezing outside!' Her sad face in the drawing (figure 4) provides further evidence that Emma did not feel included in the outdoor environment. 


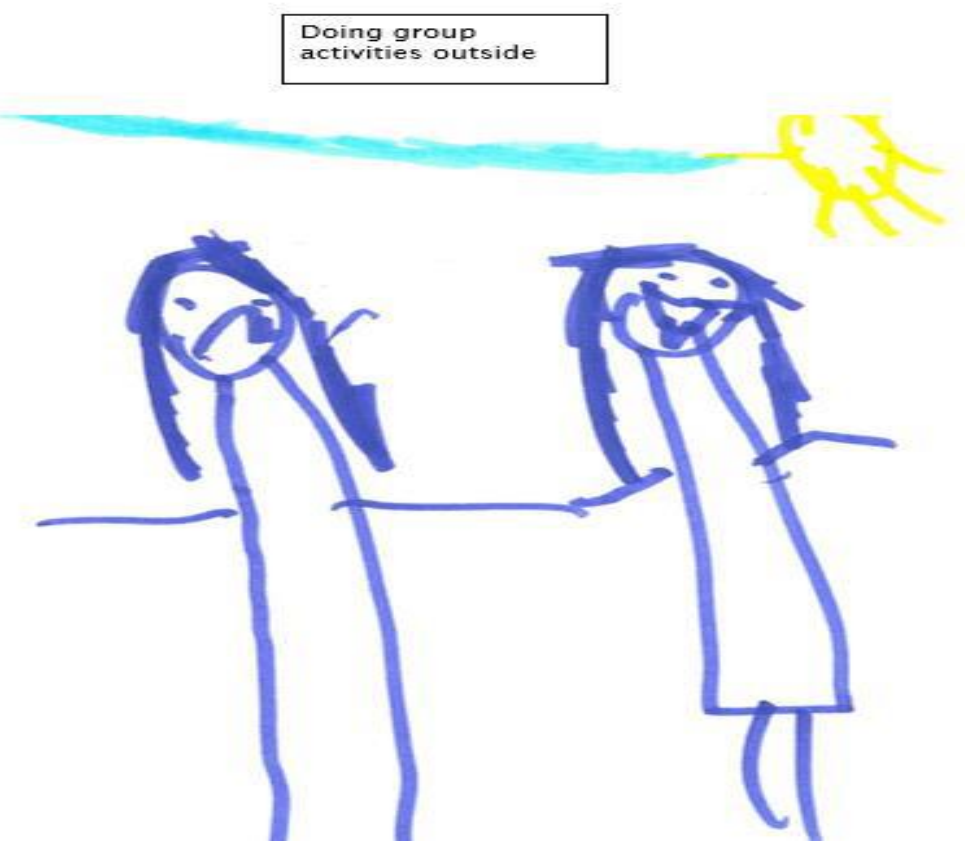

Figure 4. Emma's drawing of a pedagogical activity in which she does not perceive herself to be included.

These differing responses to the same pedagogical activity may be due to the content or the context of the pedagogical activity, or there may be alternative reasons. However, it is not important to understand why children perceive themselves to be less included, but rather a provision of opportunities should be available for children to take charge of their learning (Holec 1981). This concurs with Dam (cited in Gatherole 1990) who refers to autonomy in terms of being able to select materials, methods and tasks. Moreover, Rose and Meyer (2002) state that by giving children access to meaningful choice, by providing options that are culturally and age-relevant, and personalised and contextualised to children's lives, it will promote intrinsic motivation. Children would concentrate for longer periods of time and exhibit more outward signs of enjoyment, since they would be inherently gratified and prompted by the feeling that learning is interesting and enjoyable (Glynn et al. 2011). SirajBlatchford and Clarke (2000) refer to children needing to be in a state of emotional wellbeing and for the curriculum to be experiential, social/interactional and instructive if they are to learn. This paper extends the notion further, proposing that high levels of emotional well- 
being and involvement need to be present if children are to perceive themselves as included in pedagogical activities.

Harris (2015) reports on the necessity for early childhood education to make learning meaningful and powerful to the child's voice. The potential enhancement of inclusion for all children becomes possible by providing pedagogical activities that are sufficiently varied in content, delivery and context. This could increase children's autonomy in their learning, rather than marginalising them by practitioners' decision-making (Dahl 1982). Hart, Drummond and McIntyre (2007), however, illuminate the tension between practitioners adopting pedagogical practices that belie determinist beliefs, and their response to the external judgements of bodies, such as Ofsted. They identify that in England, school inspectors are trained to judge the extent to which teaching is differentiated by ability level (Ofsted, 2000), despite the large body of research that documents its negative effects on students self-perception (Ireson and Hallam, 2001).

In contrast, Florian and Black-Hawkins (2010) assert that inclusive pedagogical approaches can be achieved when attention is paid to everyone through the availability of diverse tasks and activities, and without the stigmatising effects of marking some students as different, particularly through perceived ability. Thus, a rationale is presented that adopts democratic practices of communicative shared experience (Dewey, 2004), where practitioner and child work together in the learning experience. It espouses Kame'enui and Carnine's (1998) position that practitioners must present learning materials (and pedagogical activities) in stimulating ways that recognise children's individuality, whilst addressing the needs of the whole class.

A further consideration of democratic pedagogy is the position of trust adopted by the practitioner, in which children know the practitioner will respond to their requests about how they learn (Hart, Drummond and McIntyre 2007). Thus, engaging with children's voices 
offers the possibility for promoting inclusion through the design of democratic pedagogies, and positions children as capable and influential beings (Prout 2000), who are actively involved in the process of learning.

\section{Limitations of the study}

Some methodological difficulties arose whilst reflecting on the research process. Firstly, using pictures of children learning in different pedagogical activities, presented some conceptual issues. The intention was to evoke discussion about the children's understanding of inclusion; however, it is acknowledged that by providing pictures that portrayed very specific ways of children working in different pedagogical environments, possible interpretations of inclusion may have been suggested. In future research, alternative pictures will be utilised that enable a child-led rather than adult-led approach.

Secondly, whilst the LIS offered a convenient starting position for collecting data that related to the children's body language and facial expressions, as the data collection progressed, its limiting factors became apparent. The language of the scale prescribed the data itself, which in turn constrained the analysis. Future research would focus more closely on unstructured observations.

\section{Conclusion}

The research study focused on an exploration of children's perceptions of inclusion in pedagogical activities in Reception classes, using participatory research tools to engage with children who have direct experience of inclusion.

The findings signify that there were two dimensions key to children's perceptions of inclusion. Firstly, belonging and relationships were noted as crucial, through the children's desire to work with one another and/or a practitioner. This reflects Wenger's (1998) positioning of learning as belonging through social communities, which has strong resonance with the principles of inclusion in terms of participation. It concurs with Rose's (2007) call 
for an approach that promotes inclusion through the provision of opportunities for children to socialise with others and engage with pedagogical activities.

Secondly, democratic pedagogies emerged from examples of children responding differently to the same pedagogical activity. This indicates that notions of inclusion are complex and multi-faceted and mean different things to different children. It offers a new critique of child-centred pedagogies, which have traditionally argued for children to have free choices about their activities (Siraj-Blatchford and Sylva, 2004). Building on Wood's (2014) notion that child-centred pedagogies do not always empower children, this research offers an insight into how child-centred pedagogical approaches could actually marginalise these children. If children are provided with pedagogical activities that require them to make decisions based on their interests and preferred ways of working, it is possible that they may perceive themselves as less included if they have insufficient skills to make such decisions. By adopting democratic pedagogies, it is conceived that children could operate in an environment of co-construction where the child and adult are equal partners, enabling children to move between structured and supportive practitioner-directed activities and more spontaneous child-initiated ones. Consequently, neither is dominating the field of shared meanings (Jordan 2004) and the practitioner 'cannot merely be an implementer ... of projects and programmes decided by and created by others, for some 'other' child and for undefined contexts' (Rinaldi 2005, 56).

The findings are of particular significance for educational contexts where formalised teaching approaches are adopted or encouraged early in children's primary education. This may result in a lack of consideration of the individuality, diversity and inclusion of children. Consequently, they raise important issues for academic research and knowledge in the international field of inclusion. Placing children's voices at the forefront of this study, 
advances the conceptualisation of the notion of inclusion by illuminating the perceptions of such a young group of children and making their voices heard.

Word count: 7711 


\section{References}

Ainscow, M. 1999. Understanding the development of inclusive schools. London: Falmer Press.

Ainscow, M. 2005. "Developing inclusive education systems: what are the levers for change?" Journal of Educational Change 6: 109-24.

Ainscow, M., T. Booth, and A. Dyson. 2006. "Inclusion and the standards agenda: negotiating policy pressures in England." International Journal of Inclusive Education, 10(4-5). Available from: http://docserver.ingentaconnect.com/deliver/connect/routledg/13603116/v10n4/s2.pdf?expires=12951 90972\&id=60713026\&titleid=358\&accname=University + of + Hull\&checksum $=7592$ CEEC6A1638B2 C7A9FEA6F10889FF

Allan, J. 2007. Inclusion for all? Available from: https://dspace.stir.ac.uk/bitstream/1893/596/1/Scottish-Education-paper2007.pdf

Allodi Westling, M. 2002. "Children's experiences of school: Narratives of Swedish children with and without learning difficulties." Scandinavian Journal of Education Research, 46(2): 181-205.

Angelides, P., and A. Michaelidou. 2009. "The deafening silence: discussing children's drawings for understanding and addressing marginalization." Journal of Early Childhood Research 7(1): 27-45.

Baumeister, R.F., and M.R. Leary. 1995. "The need to belong: Desire for interpersonal attachments as a fundamental human motivation." Psychological Bulletin 117(3): 497-529.

Benjamin, S. 2002. The micropolitics of inclusive education. Buckingham: Open University Press.

Bennett, M. 2011. “Children's Social Identities.” Infant and Child Development 20: 353-63.

Blaise M., and S. Ryan. 2012. "Using Critical Theory to Trouble the Early Childhood Curriculum: Is it enough?" In Curriculum in Early Childhood: Reexamined, Rediscovered, Renewed, edited by N. File, J. Mueller, and D. Wisneski, 80-92. New York: Routledge.

Blenkinsop, S. 2005. "Martin Buber: Educating for Relationship." Ethics, Place and Environment 8(3): 285-307.

Booth, T., and M. Ainscow. 2004. Index for inclusion: Developing learning, participation and play in early years and child care. Bristol: CSIE.

Boxall, K., and S. Ralph. 2009. "Research Ethics and the use of Visual Images in Research with People with Intellectual Disability." Journal of Intellectual and Developmental Disability 34(1): 4554.

Bruce, T. 2001. Learning Through Play, For Babies, Toddlers and Young Children (Introduction to Child Care). $2^{\text {nd }}$ ed. Oxon: Hodder Education.

Bryman, A. 2012. Social Research Methods. $4^{\text {th }}$ ed. Oxford: Oxford University Press.

Cagliari, P., A. Barozzi, and C. Giudici. 2004. "Thoughts, theories and experiences for an educational project with participation." Children in Europe 6: 28-30.

Campbell, C. 2002. "Conceptualisations and definitions of inclusive schooling." In Developing Inclusive Schooling: perspectives, policies and practices, edited by C. Campbell, 11. London, Institute of Education: University of London. 
Candy, P.C. 1991. Self-direction for Lifelong Learning. California: Jossey-Bass.

Children and Young People's Unit. 2004. Core Principles of Participation. Available from: http://www.cypu.gov.uk/corporate/participation/coreprinciples.cfm.

Clark, J. 2012. "Using diamond ranking as visual cues to engage young people in the research process." Qualitative Research Journal 12(2): 222-37.

Clark, A., S. McQuail, and P. Moss. 2003. Exploring the field of listening to and consulting with young children. Research Report 445, London: DfES.

Cohen, L., L. Manion, and K. Morrison. 2007. Research Methods in Education. $6^{\text {th }}$ ed. London: Routledge.

Collier, J. Jr. 1957. "Photography in anthropology: a report on two experiments." American Anthropologist, New Series 59(5): 843-59.

Cruddas, L. 2006. "Engaged Voices - Dialogue Interaction and the Construction of Shared Social Meanings." Educational Action Research 15(3): 479-88.

Dahl, R.A. 1982. Dilemmas of pluralist democracy: autonomy and control. New Haven, Yale: University Press.

Dam, L. 1990. Learner Autonomy in Practice. In CILT, edited by I. Gathercole, 16. Great Britain: Bourne Press.

Department of Education Employment and Workforce Relations. 2009. Belonging, Being, Becoming: The Early Years Learning Framework for Australia. Canberra: Commonwealth of Australia. Available from: http://docs.education.gov.au/system/files/doc/other/belonging_being_and_becoming the_early_years _learning_framework_for_australia.pdf.

Dewey, J. 2004. Democracy and Education. New York: Dover Publications (originally published 1916).

DfE. 2014. Statutory framework for the early years foundation stage. Setting the standards for learning, development and care for children from birth to five. Available from: http://www.foundationyears.org.uk/files/2014/07/EYFS framework from 1 September 2014 with clarification note.pdf.

DfE. 2015. Special educational needs and disability code of practice: 0 to 25 years. Statutory guidance for organisations which work with and support children and young people who have special educational needs or disabilities. Available from: https://www.gov.uk/government/uploads/system/uploads/attachment_data/file/398815/SEND_Code_ of_Practice_January_2015.pdf.

Dockett, S., and B. Perry. 2005. "Researching with Children: insights from the Starting School Research Project." Early Child Development and Care 175(6): 507-21.

Dockett, S., B. Perry, and E. Kearney. 2012 "Promoting children's informed assent in research participation." International Journal of Qualitative Studies in Education 44(3): 287-305.

Dyson, A. 1999. "Inclusion and Inclusions: theories and discourses." In World Yearbook of Education 1999: Inclusive Education, edited by H. Daniels, and P. Garner, 36-53. London: Kogan Page. 
Einarsdottir, J. 2010. "Children's experiences of the first year of primary school." European Early Childhood Education Research Journal, 18(2): 163-80.

Fargas-Malet, M., D. McSherry, E. Larkin, and C. Robinson. 2010. "Research with children: Methodological issues and innovative techniques." Journal of Early Childhood Research 8(2): 17592.

Florian, L. 2008. "Special or inclusive education: future trends." British Journal of Special Education, 35(4): 202-8.

Florian, L. and K. Black-Hawkins. 2010. "Exploring inclusive pedagogy.” British Educational Research Journal 37(5): 813-28.

Glynn, S.M., P. Brickman, N. Armstrong, and G. Taasoobshirazi. 2011. "Science motivation questionnaire II: validation with science majors and nonscience majors." Journal of Research in Science Teaching 48: 1159-76.

Greene, S., and M. Hill. 2005. "Researching Children's Experience: Methods and Methodological Issues." In Researching Children's Experience, Approaches and Methods, edited by S. Greene and D. Hogan, 1-21. London: Sage.

Hadfield, M. and K. Haw. 2001. “Voice', Young People and Action Research.” Educational Action Research 9(3): 485-502.

Harris, K.I. 2015. "Developmentally universal practice: visioning innovative early childhood pedagogy for meeting the needs of diverse learners." Early Child Development and Care 185(11-12): 1880-93.

Hart, S., M.J. Drummond, and D. McIntyre. 2007. "Learning without limits." In The Sage Handbook of Special Education, edited by L. Florian, 499-514. London: Sage.

Hedges, H. and J. Cullen. 2011. "Participatory learning theories: a framework for early childhood pedagogy." Early Childhood Development and Care, 182(7): 921-40.

Holec, H. 1981. "Autonomy in Foreign Language Learning." In Autonomy and Independence in Language Learning, Benson, P. and P. Voller. London: Longman.

Ireson, J. and S. Hallam. 2001. Ability grouping in education. London: Paul Chapman.

James, A., and A. James. 2008. Key concepts in childhood studies. London: Sage.

Jameson, K. 1968. Preschool and infant art. London: Studio Vista.

Jordan, B. 2004. "Scaffolding learning and co-constructing understandings." In Early childhood education: Social and cultural perspectives, edited by A. Anning, J. Cullen, and M. Fleer, 31-42. London: Sage.

Joerdens, S. 2014. “'Belonging Means You Can Go In': Children's Perspectives and Experiences of Membership in Kindergarten." Australasian Journal of Early Childhood 39(1): 12-21.

Kame'enui, E.J. and D.W. Carnine. 1998. Effective teaching strategies that accommodate diverse learners. Upper Saddle River, NJ: Merrill.

Komulainen, S. 2007. "The ambiguity of the child's "voice" in social research." Childhood 14: 11-28. 
Kragh-Müller, G., and R. Isbell. 2011. "Children's perspectives on their everyday lives in child care in two cultures: Denmark and the United States. Early Childhood Education Journal 39(1): 17-27.

Laevers, F. 1994. "The innovative project Experiential Education and the definition of quality in education." In Defining and Assessing Quality in Early Childhood Education edited by F. Laevers. Studia Paedagogica Leuven: Leuven University Press.

Levin, I. 1994. "Children's perceptions of their families." In Childhood and Parenthood, edited by J. Brannen, and M. O’Brien, 55-74. London: Institute of Education.

Liasidou, A. 2012. Inclusive Education, Politics and Policymaking (Contemporary Issues in Education Studies). London: Continuum International Publishing Group.

Lundqvist, J., M. Westling Allodi and E. Siljehag (2018) "Values and Needs of Children With and Without Special Educational Needs in Early School Years: A Study of Young Children's Views on What Matters to Them." Scandinavian Journal of Educational Research 1-17.

MacNaughton, G., P. Hughes, and K. Smith. 2007. "Young Children's Rights and Public Policy: Practices and Possibilities for Citizenship in the Early Years." Children and Society 21: 458-69.

Malaguzzi, L. 1993. "History, Ideas and Basic Philosophy." In The Hundred Languages of Children, edited by C. Edwards, L. Gandini, and G. Forman, 41-9. New York: Ablex Publishing.

Messiou, K. 2006. "Understanding Marginalisation in Education: the Voice of Children." European Journal of Psychology of Education 21(3): 305-18.

Messiou, K. 2016. Research in the field of inclusive education: time for a rethink? International Journal of Inclusive Education 21(2), 146-59.

Ministry of Education. 1996. Te Wha riki: Early Childhood Curriculum. Wellington: Learning Media Limited. Available from:

http://www.educate.ece.govt.nz/*/media/Educate/Files/Reference\%20Downloads/whariki.pdf.

Moss, P. 2007. Bringing Politics into the Nursery: Early Childhood Education as a democratic practice. Thomas Coram Research Unit: Institute of Education University of London. Available from: http://eprints.ioe.ac.uk/5603/1/Moss2007Bringing5.pdf.

Nutbrown, C. and P. Clough. 2009. "Citizenship and inclusion in the early years: understanding and responding to children's perspectives on 'belonging'." International Journal of Early Years Education 17(3): 191-206.

O’Brien, J. and M. Forest. 1989. Action for Inclusion: How to Improve Schools by Welcoming Children with Special Needs into Regular Classrooms. Toronto: Inclusion Press.

Office of the High Commissioner for Human Rights. 2005. General Comment No. 7 Implementing Child Rights in Early Childhood. Available from:

http://www.ohchr.org/english/bodies/crc/comments.htm.

Ofsted. 2000. Evaluating educational inclusion guidance for inspectors and schools. London: Ofsted.

Picard, D., C. Brechet, and R. Baldy. 2007. "Expressive strategies in drawing are related to age and topic." Journal of Nonverbal Behaviour 31: 243-57.

Prout, A. 2000. "Children's Participation: Control and Self-Realisation in British Late Modernity." Children and Society 14: 304-15.

Rathbone, C.H. 1971. Open Education: The Informal Classroom. New York: Citation Press. 
Rinaldi, C. 2005. In dialogue with Reggio Emilia. London: RoutledgeFalmer.

Ritala-Koskinen, A. 1994. Children and the construction of close relationships: how to find out the children's point of view. In Childhood and Parenthood, edited by J. Brannen, and M. O'Brien, 30917. London: Institute of Education.

Rockett, M. and S. Percival. 2002. Thinking for Learning. Stafford: Network Educational Press.

Rolfe, G., D. Freshwater, and M. Jasper. 2001. Critical reflection in nursing and the helping professions: a user's guide. Basingstoke: Palgrave Macmillan.

Rose, R. 2007. "Curriculum consideration in meeting special educational needs." In The Sage Handbook of Special Education, edited by L. Florian, 295-306. London: Sage.

Rose, D. and A. Meyer. 2002. Teaching every student in the digital age: Universal design for learning. Alexandria, VA: Association for Supervision and Curriculum Development.

Schwandt, T.A. 1997. Qualitative inquiry: A dictionary of terms. Thousand Oaks, CA: Sage Publications, Inc.

Siraj-Blatchford, I. and P. Clarke. 2000. Supporting Identity, Diversity and Language in the Early Years. Buckingham: Open University Press.

Siraj-Blatchford, I. and K. Sylva. 2004. "Researching pedagogy in English pre-schools." British Educational Research Journal 30(5): 713-30.

Siraj-Blatchford, I., K. Sylva, S. Muttock, R. Gilden, and D. Bell. 2002. Researching Effective Pedagogy in the Early Years. University of Oxford: Department of Educational Studies.

Slee, R. 1998. "The politics of theorising special education.” In Theorising Special Education, C. Clark, A. Dyson, and A. Millward, 122-36. London: Routledge.

Slee, R. 2001. “Inclusion in practice: Does practice make perfect?" Educational Review 53(2): 113 23.

Smart, C. 2009. "Shifting horizons: Reflections on qualitative methods." Feminist Theory 10(3): 295308.

Stephen, C. 2010. "Pedagogy: The silent partner in early years learning." Early Years 30(1): 15-28.

Strauss, A. and J. Corbin. 1994. "Grounded theory methodology: An overview." In Handbook of qualitative research, edited by N. Denzin and Y.S. Lincoln, 273-85. Thousand Oaks, CA: Sage.

Sumsion, J. and S. Wong. 2011. "Interrogating 'belonging' in Belonging, Being and Becoming: The Early Years Learning Framework for Australia." Contemporary Issues in Early Childhood 12(1): 2845 .

Thomas, D.R. 2006. "A General Inductive Approach for Analyzing Qualitative Evaluation Data." American Journal of Evaluation, 27(2): 237-246

Thomas, G. and A. Loxley. 2007. Deconstructing special education and constructing inclusion, $2^{\text {nd }}$ ed. Maidenhead: McGraw-Hill/Open University Press.

Turnbull, N., T. Fattore, and M. Calder. 2008. Engaging with children: The political dimension, The Carrot or the Stick? Towards Effective Practice with Involuntary Clients in Safeguarding Work. Lyme Regis: Regis Russell House.

UNCRC. 1989. Convention on the Rights of the Child. New York: United Nations. 
Wenger, E. 1998. Communities of practice: learning, meaning, and identity. Cambridge University Press.

Wood, E.A. 2014. "Free choice and free play in early childhood education: troubling the discourse." International Journal of Early Years Education 22(1): 4-18.

Woodhead, M. 2009. "Childhood studies. Past, present and future." In An introduction to childhood studies, edited by M.J. Kehily, 17-33. Maidenhead: Open University Press.

Yuval-Davis, N. 2006. "Belonging and the politics of belonging." Patterns of Prejudice 40(3): 197214. 